\title{
Pauline Imperatives (Eph. 4:31-32): Necessities for the Enhancement of Christian Faith and National Integration.
}

\author{
by \\ Rev. Fr. Dr. Ezeogamba Anthony (08033895095) \\ Chukwuemeka Odumegwu Ojukwu University Anambra State
}

Eph. 4:31-32 urges believers to, "Put away all bitterness and wrath and anger and wrangling and slander, together with all malice, and be kind to one another, tenderhearted, forgiving one another, as God in Christ has forgiven us." The above is strongly worded. A cursory look at the Nigerian nation reveals that Nigeria as a nation is sectionalized along ethnic, religious as well as gender line. Apart from the three main dominant ethnic groups in Nigeria, there are still very many ethnic groups that are not even recognized and they feel marginalized and out of the equation. There is unwritten and unexpressed anger that exists among all the three major ethnic groups in Nigeria; each claiming to have been marginalized by others. Again, there are three main religious groups in Nigeria namely, Islam, Christianity and African Traditional Religion. Among these three dominant groups, there is deep-rooted antagonism. Hence, each of these religious groups is internally divided. There are so many sects in Islam and in most cases they are at each other's throat. In the same way, there are several denominations or sects in Christianity and each of the sets claim to be with the authentic doctrine to the neglect and detriment of others. African Traditional Religion on her part is localized in each region and each region claims that theirs is more authentic and more godly than of others. The worst hatred is between the so-called infidels and Muslim believers. Any nation that has the above qualities, has unknowingly taken underdevelopment, and godlessness as her second name. This paper sets out to prove that if there is mutual love among all the ethnic groups in Nigeria, among religious groups both ad extra and within, then godliness will prevail everywhere and Nigeria as a nation will be better for it. This paper argues that a proper understanding and appreciation of Eph. 4:3132 by Christians and none Christians alike will emit so many green lights that could promote nation building and oneness. Significantly, this paper will be of immense benefit to all men and women of good will both in Nigeria and outside Nigeria.

key words: Bitterness, Kindness, Compassion and Forgiveness.

\section{Introduction}

There can never be any meaningful development where violence, hatred, injustice, deprivation as well as man's inhumanity to man is the order of the day. Development is possible where love abounds. Just as it is always rare to have a child that grows from a divided family and yet faces no social deviation, it is even so rare to have a meaningful development in a factionalized country, state, local government, towns, villages as well as kindred. Holy Writ even emphasized that, "Every kingdom divided against itself will be ruined, and every city or household divided against itself will not stand" (Matt. 12:25). Bur affirmed the above when he said, 
Conflicts are largely responsible for the backwardness of a country. Such crises hinder the people from active participation in the economic, social and political progress of the country. It is evidently clear from the Gross National Product of the country that states are backward especially those states that are crises-prone. The other side effects are on the schools, houses, churches, mosques and displacements of people in the rural areas especially the women and children. Obviously, the effects of this phenomenon on Nigeria can best be seen than imagined. ${ }^{1}$

A good example is the Northeastern part of Nigeria where education, road construction, social amenities like pipe born water, telecommunication outfits, electricity and even housing schemes are at a standstill as a result of the Shiites Muslims and the terrorist group named Boko Haram. A similar situation obtains in South- South part of Nigeria, where the so called militants like the Movement for the Emancipation of Niger Delta (MEND), Movement for the Survival of Ogoni People (MOSOP), the Egbesu Boys; the Niger Delta Volunteer Force (NDVF); Congress for the Liberation of Ikwere People (COLIP) and Chikoko Movement. The last two militant groups were under the leadership of Asari-Dokubo (2004-2005). They all took up arms in anger against the Nigerian government for the neglect and injustice they perceived they are suffering in Nigeria. Some people have even alleged that these militants fought with the sole intention of forcing Nigeria to disintegrate or for better condition to emerge. This is because their environment according to them has been allegedly destroyed by the Nigerian government as a result of oil exploration in their area. When the militants that have been agitating on behalf of the Niger Delta (South-South) zone seemed to have been compromised, another deadly militant group named Niger Delta Avengers (NDA) emerged. This group emerged shortly after former president Goodluck Jonathan lost his re-election bid. This idea is what made some people to argue that NDA and indeed other militants have the backings of former President Goodluck Jonathan. $^{2}$ It is not an exaggeration to say that NDA is more deadly than other militant groups before it. In 2016, the actions of NDA forced major oil companies including Shell, Agip, and Chevron to cease operations and withdraw their staff from the Niger Delta. It is a fact that between mid-January and mid-November 2016, it claimed responsibility for about 50 attacks on oil installations mostly in Delta and Bayelsa States. This was done in the effort to bring Nigerian oil production to Zero point. The reason behind the attacks was to allegedly end the widespread poverty and environmental degradation across the Niger Delta area. Hence, through their effort, Nigerian foreign earning as well as electricity came to a temporal halt. ${ }^{3}$ Anyone who sees their environment today will naturally ask some questions.

\footnotetext{
${ }^{1}$ Bur, A. The Dynamics of Conflict Resolution and National integration: The Nigerian Experience. Apaper Presented at the 25th Annual Conference of the Counseling Association of Nigeria (CASSON), Makurdi from 20th - 24th August 2001.

2 Hassan Adebayo, "Why We Renewed Attacks on Oil Facilities - Niger Delta Avengers" in Premium Times (November 14, 2016) www.premiumtimesng.com/news/top. Sourced on Saturday, March 4, 2017

${ }^{3}$ Samuel Ogumdipe, "Niger Delta Avengers accuses Buhari of stalling peace talks, vows renewed attacks" in Premium Times (January7, 2016) www.premiumtimesng.com/news/headlines. Sourced on Saturday, March 4, 2017
} 
Furthermore, the people of South Eastern part of the country are also agitating against their alleged marginalization by the Nigerian nation since the inception of the nation as an independent nation. This idea led the region to carry arms against Nigeria so as to force the Nigerian government to address the issue. Incidentally, that never solved the problems which the people felt they were suffering from. This further gave rise to secessionist groups like Movement for the Actualization of the Sovereign State of Biafra (MASSOB). After some years, another group emerged accusing MASSOB of having been compromised by the Nigerian government, hence the formation of yet another group tagged, the Indigenous people of Biafra (IPOB). These groups claim to be peaceful in their agitation but thousands of them have been killed by the federal forces. If not for the enterprising nature of the people of the South East, their land would have remained devastated like others we have mentioned above.

The West part of Nigeria has her own militant groups that are fighting for the people of the Yoruba race. They also feel marginalized in the Nigerian nation. The group they formed is the Odua People's Congress (OPC). Just as their counterparts in the South-South section of the country, OPC has also been alleged to be involved in the breaking of pipelines, stealing and kidnappings. Their Northern counterpart, Boko Haram terrorist group has allegedly gone about kidnapping, maiming and killing people as well as destroying people's properties that may have run into trillions of naira. This group is being accused of terrorizing everybody through the destruction of lives and properties and they are nearly getting Nigeria grounded. This group nearly made Nigeria ungovernable under GoodLuck Ebele Jonathan, the former president of Nigeria. Though today Boko Haram has intensified its destructive tendency but one can rightly say that what Avengers are doing today under President Muhammadu Buhariis exactly what Boko Haram group did under President Goodluck Ebele Jonathan. How did we find ourselves to where we are today. An author rightly pointed out that "Immediately after the handover in May 29th, 1999, the country witnessed two successive security challenges, namely the Odi crisis of 1999 and the communal violence in Jos in 2000. These were followed by electoral violence in 2003, 2007 and later in 2011. In an attempt to win elections, by all means, Nigerian politicians usually assemble some youth gangs and used them as things after which they were dumped without tangible thing to sustain their lives." ${ }^{4}$ This reveals that the problem of factions in Nigeria that is the bane of development was directly and remotely caused by the leaders and the enlightened. The enlightened and leaders were without foresight and were bedeviled by impunity. Above all, religious intolerance has aggravated the politicized and factionalized Nigeria and nearly grounded the nation.

The above reveals the level of bitterness, wrath, anger, wrangling and slander, together with all malice in Nigeria today. As a result of these negative attributes, Nigeria is not growing and has reached the point of collapsing if there is no divine intervention soonest. As a result of these struggles, unforgiving spirit pervade the land (Eph 4:31), almost every section of the country has

${ }^{4}$ Babatunde Joseph Osabiya, "Ethnic Militancy and Internal Terrorism on Nigeria's National Security" in International Journal of Development and Conflict 5(2015) 59-75. 
lost a lot. Hence, development and nation building is grounded to a halt. This article calls every section of Nigeria to be kind to one another, tenderhearted, forgiving one another, as God in Christ has forgiven us (Eph. 4:32). For want of space, we shall look only in detail the militant groups in the South-South and South East and make inference to the ones in the South West and North. We shall group our studies into six sections namely (1) The Militant Groups in the Niger Delta (2) The Militant Groups in the South East (3) Exegesis of Eph. 4:31-32 (4) Evaluation (5) Recommendations (6) Conclusion.

\section{The Militant Groups in the Niger Delta}

The first question that one would ask is, what are the cause(s) of conflict or crisis in Niger Delta? The underlying cause of violence in the Niger Delta region of Nigeria is the fact that all ethnic groups in Nigeria are feeling marginalized. The Niger Delta people are mostly fishermen and women, hunters and farmers. Before oil was discovered in commercial quantity in the area around 1958 they were highly contented with what their natural environment could offer them. Their land was highly fertile and their water bodies provided good breeding ground for aquatic animals like fish and other animals of different species. Land animals that made up of their delicacy are innumerable, prominent among them were squirrels, grasscutter, etc. These are becoming history. They had good drinking water that was readily available. They never thought about having to struggle to construct fish ponds, swimming pools etc because these were naturally provided for them by nature. Their atmosphere was highly purified but today as a result of the magnitude of gas flaring, one hardly enjoys cool and fresh air even at the dead of the night. Their water bodies are today highly polluted. Thus, aquatic lives are highly endangered. Their water oozes out stench odour of putrefying animals. Roads are not constructed. The oil wells are owned by non-indigenes of Niger Delta. The most excruciating part of this ugly situation is that the former farmers, hunters and fishermen and women are rendered jobless. The various complaints of the youths merit them peanuts that offer them temporal relief. Incidentally, the oil that flows out of their land is the major export product of Nigeria and what majorly funds Nigerian budget since the discovery of this oil. Any Niger Delta person who travels out of the Niger Delta area and visits former Dodan Barrack (former Nigerian seat of government in Lagos) as well as Lagos, Abuja, the present capital of Nigeria, and Aso-Rock and even visits any Shell, Elf and Agip quarters will definitely shed tears especially if he knows that those places were constructed using the proceeds from the oil pumped out of their land. Since the discovery of how marginalized they are, the type of news headlines that comes out from that region is like this, "Nigeria loses N3.45bn daily as Shell shuts Bonga;" 5 "Crude oil theft: Military nabs 3, destroys 80 illegal refineries." ${ }^{6}$ In the same vein, Akokona reports most recently thus,

Warri- Crisis is looming in Egbema Kingdom, Warri North Local Government Area, Delta State, as the people of the area have given Niger Delta Development Commission, NDDC, a 21-day ultimatum to kick-start all abandoned projects in their communities. Tsekelewu and Polobobou communities said that failure to comply will lead to civil disturbances and disruption of operations of oil

\footnotetext{
${ }^{5}$ Femi Asu, Nigeria Loses ..." in Punch Newspaper (punchng.com/nigeria-loses-n3-45) March 7, 2017.

${ }^{6}$ Femi Folaranmi, "Crude oil theft: Military nabs 3, destroys 80 . . ." in the Sun Newspaper

(http://sunnewsonline.com/crude-oil-theft-military-nabs-3) March 7, 2017.
} 
companies in their area. The communities also called on Chevron Nigeria Limited to commence the dredging of Tsekelewu and Pelobobou creeks for easy accessibility to their communities, alleging that Chevron operations in their area have succeeded in converting their creeks to ordinary land and difficult to enter. ${ }^{7}$

Even a long time before the above, it is good to note with some nostalgia that around 2005, Newswatch allegedly reported that Asari- Dokubo accused Federal Government of Nigeria thus, "Nigerian state is stealing from us; we say no more stealing of our resources. Give it back to us. Our language and our culture, which the Nigeria constitution has dubiously eliminated. We are saying that we were forced by force of arms to be Nigerians, we are not Nigerians. We are Ijaw people." ${ }^{8}$ Such are constant headlines one is most likely to see in our national daily newspapers.

Again, the result of the research carried out by Johnson Osagie et al among the Niger Delta youths "revealed that deprivation of the indigenes of the dividends of oil proceeds which is under economic factor accounted for the greatest cause of conflict and closely following it was political factor. The result also revealed that religion and ethnicity have a great influence on the conflicts. ${ }^{9}$ The anger is most often expressed in the conflicts that ensues most often between the local communities and multinational companies operating in the Niger Delta area. For instance, Obubutu versus Elf in October, 1989; Umuechem versus Shell in October, 1990; Uzere versus Shell in July, 1992; Ogoni versus Shell, this one started around 1990 and are still unabated even till today. These wars are not really being waged purely by these locals and the multinational as such but are engineered by one militant group or the other. As we have listed above, the following are the most popular militant group fighting for the control of their God given natural resources; MEND, MOSOP, Egbesu Boys, NDVF and NDA. The last group seems to be the most deadly and at the forefront for the demand of the control of their natural resource; development of their region and protection of their environment. In June last year (2016), for instance, the spokes person of Niger Delta Avengers warned when they felt that Government is not serious with the dialogue they initiated,

The NDA high command is restating our commitment to attack the interest of oil corporation and international refineries operators that bring in vessels to the Niger delta territory to buy our oil that every successive government have refused to used and reapply the proceeds towards any development in the region since 1958. If they refuse be heed to our advice will result to sinking two of their mother vessel as an examples to others. They should not undertake any repair of pipeline, oil and gas facilities that is damaged or attacked by our forces during this period of 'Operation Red Economy' until and/or after the dialogue. ${ }^{10}$

\footnotetext{
${ }^{7}$ Akolona Omafuaire, "Crisis looms as Delta communities give NDDC, Chevron 21-day ultimatum" in the Vanguard Newspaper (March 8, 2017) http://www.vanguardngr.com/2017/03/crisis-looms-as-delta-communities-give-nddcchevron-21-day-ultimatum/ ${ }^{8}$ Tobs Agbaegbu, "Crackdown on Militias" in Newswatch (vol. 42, no.16) October 17, 2005

9 Johnson Osagie; AkinpoluFunmilayo;Adegoke Fred; Ezeani Samuel. "Causes of Conflict in the Niger Delta Region of Nigeria Expressed by the Youth in the Niger Delta State" in Procedia Social \& Behavioral Sciences 5(2010) 82-89. (www.sciencedirect.com/science/article/pii.) sourced on 4th January, 2017. ${ }^{10}$ Ogumdipe, S. "Niger Delta Avengers gives conditions for talks with Nigerian govt."
} 
Every Nigerian is aware of what happened after such warnings. Several countries declared Niger Delta unhealthy for their nationals and such countries include: United States of America, Britain, Canada and Australia etc. Nigeria has not really recovered from the effects of NDA on the 2016 and even 2017 budgets. Warri and indeed all Riverine areas of Nigeria will never forget in a hurry what these conflicts caused them. This is no doubt, one of the major things that threw Nigeria into recession, and backwardness of all the states of the Federation since every state depends on monthly allocation from the federal government for almost everything. Next is the story of South Eastern part of Nigeria.

\section{The Militant Groups in the South East}

A brief history may help us at this stage to throw more light on the militants in the Niger Delta. The Eastern Region was an administrative region in Nigeria, dating back originally from the division of the colony of Southern Nigeria in 1964. Its first capital was Calabar. The capital was later moved to Enugu and the second capital was Umuahia probably during the NigeriaBiafra war. The region was officially divided in 1967 into three new states, the East-Central State, Rivers State and South-Eastern State. The East-Central State had its capital at Enugu, which is now part of Enugu state. The region had then three major ethnic groups namely Igbo, Ibibio, and Ijaw with other numerous ethnic groups. It was this region as a region that metamorphosed into Biafra which carried arms against Nigeria from 1967 to 1970. The implication of this is that Niger Delta militant groups are part of South East in their agitation. ${ }^{11}$. Whatever the MASSOB and IPOB agitate against they are doing it both remotely and immediately for the people of South-South and South Eastern area. Whatever we say here about MASSOB or IPOB, therefore, has the interest of the entire South East even though externally, it would seen as if it concern the Igbo alone. We shall therefore now consider mainly the agitation as was led primarily by East central states which embraces today five states namely, Abia, Anambra, Ebonyi, Enugu, and Imo.

People suggested the most likely things that led to Nigerian -Biafran war: Prominent among them was both political and economical feeling of marginalization by the Igbo. Politically because the Federal Government then was nothing short of Northern dominated. Economically, there was not much the federal government presence in the region coupled with the fact that after the civil war, no matter the amount one had in the bank everybody was paid $£ 20$. This situation was aggravated by a military coup of 1966 as well as a counter-coup and alleged persecution of the Igbo as a result of the coup. The Igbo people were accused of master minding the first coup and Hausa people masterminded the counter-coup and subsequently in control of all that happened after that coup. The war ended eventually with three great "Rs" namely, reconciliation, reconstruction and rehabilitation. It is a fact that, the implementation of these three "Rs" have not seen the light of the day. Majority of Igbo is of the opinion that the three "Rs" have been transformed into retaliation, isolation and maximum hatred. To make it worst, no South Easterner has been elected the president of Nigeria since the end of the civil war ${ }^{12}$. Alex Ekwueme and Emmanuel Iwuanyanwu struggled to be president of Nigeria but they were frustrated. Alex Ekwume in view of the above, regrettably says,

\footnotetext{
${ }^{11}$ https://en.wikipedia.org/wiki/Eastern_Region,_Nigeria Copied on 08/03/2017

${ }^{12}$ Raph Umazuruike, Northern Conspiracy Won't Allow Igbo Presidency

https://www.today.ng/news/nigeria/269061/northern-conspiracy-allow-igbo-presidency-uwazuruike (March 8, 2017)
} 
I was Vice President until December 1983 and going by the old NPN order, I would have contested for the number one position in 1987, but the military intervened in 1983 and the civilian regime was cut short. I tried again in 1998 and Obasanjo was released from prison and he came and won, supported by his colleagues in the military. I tried again in 2003 and the same thing happened. I therefore pray that the other people (Igbo) can take it up from there and make progress. $^{13}$

This type of thought was what led to the emergence of MASSOB and IPOB. Hence, Uwazuruike said,

The anger which led me to demand the resuscitation of Biafra republic had to do with the soiled relationship between Ndigbo and the rest of Nigerians since the January 15, 1966 by Major Chukwuma Nzeogwu led military coup. The Hausa/Fulani and Yoruba conspiracy against Ndigbo is real and that was why the former Defence Minister, Gen. Theophilus Danjuma (retd) could also not hide his own feeling and hatred for Ndigbo when he made an open declaration that he would go into exile than allow Dr. Ekwueme to be President of Nigeria ${ }^{14}$.

MASSOB is a secessionist movement with the aim of securing the resurgence of the defunct state of Biafra from Nigeria. It is led by an Indian-trained lawyer Ralph Uwazuruike with headquarter in Okwe, in the Okigwe district of Imo state. Since its inception, in its bid to emancipate the South East, MASSOB has done the following: hoisting of Biafran flag as a sovereign nation in South-South and South Eastern part of Nigeria. It has organized very many protests to drive their points home about allowing them to be an independent nation. It equally introduced Biafran currency as a nation in 2005 and finally it introduced Biafran passport in 2009. ${ }^{15}$ All these actions attracted persecutions, imprisonments, loss of lives and properties.

Another more aggressive group - IPOB emerged claiming that the other group - MASSOB has been compromised. This group has Nnamdi Kanu as its leader. This group intensified all that have been done earlier by MASSOB and even more arrogant in their pursuit. For this group, it is either 'Biafra or death.' Hence, her members are ready to die for what they believe in. From the date of the emergence of IPOB till date, it has witnessed several attacks from the military authority. This has led to so many altercations between the group and Nigerian government. For instance, Emma Powerful, one of the spokesmen of IPOB warned, lamenting and alleging that,

The police and army, acting on the instructions of the presidency, carried out the 7th cold bloodied massacre of IPOB members since August 30th 2015 at Uga/Atani junction in Ogbaru LGA of Anambra State. This disgraceful episode

\footnotetext{
${ }^{13}$ Uwazurike, Northern Conspiracy.

${ }^{14}$ Uwazurike, Northern Conspiracy.

15 The Free Encyclopedia, Movement for the Actualization of the Sovereign State of Biafra. (https//en.wikipedia.org/wiki/movement-for-the-actualization). Sourced on March 8, 2017.
} 
of state sponsored terrorism will inevitably lead to armed conflict sooner or later unless the culprits are brought to book. ${ }^{16}$

The above was sparked by the alleged killing of the members of IPOB on 20th January, 2017 as they demonstrated in the streets of Port Harcourt in solidarity with the inauguration of President Trump's government in far away USA. They warned and notified the general public that from hence onward, the IPOB will no longer march without self-defensive mechanism in place. Senator Enyinna Abaribe, the chairman of the South East senators' caucus raised his voice and condemned the alleged killing of IPOB members thus, "If the report of killings by the security agencies were to be confirmed, it would no doubt leave a gaping hole in the unity of this country. This is one regrettable action too many, coming against the backdrop of the recent report of the Amnesty International (AI) of mass killings of people from the same section of the populace in Nigeria." ${ }^{17}$ This group as we know already is working in harmony with any group in the region that is honestly struggling for the emancipation of any section of South-South and South East section of Nigeria. This fact is authenticated by Chiamaka Okoh while reporting the opinions of Emma Nmezu and Clifford Iroanya (other spokespersons for IPOB) reiterated,

The group and its leader, Mazi Kanu, are in full support of any group of dedicated and hardcore freedom fighters such as the Niger Delta Avengers (NDA), owing to the fact that they all share the same aspiration which is the liberation of our people. Stressing that the restoration of the nation of Biafra is not subject to negotiation, and that if there should be negotiations at all, it must be centered on asset sharing between Nigeria and Biafra and on the payment of reparations for money stolen from Biafrans by Nigeria through the 1970 twenty pounds deal and other subsequent acts of thieving by Nigeria against Biafrans. ${ }^{18}$

The above no doubt shows us that the South-South and South East are angry with the Nigerian nation. Let us therefore briefly look at the Western part of the nation. Just as the South-South, and South East are angry with the Nigerian Government, South West and North are also angry with the way things are going on in Nigeria of today. OPC is fighting in the South West and Boko Haram's activities are not hidden at all in Nigeria not to talk of the activities of Fulani herdsmen. Nigeria is therefore terrorized from every angle. It is no exaggeration to claim that every part of Nigeria is boiling. The above situations have given the military and indeed all the Law Enforcement Agents reason to be on their toes. In order to contain the situation, the military has launched the following operations: First and foremost, there is Joint Task Force (JTF) operation in all the states of Nigerian Federation. Every region in Nigeria has military dedicated operation so as to tackle insurgence. In the North East there are Operation Lafiya Dole, Operation Crackdown, Operation Gama Aiki, and Operation Safe Corridor. In the North Central is Operation Safe Heaven. This is aimed at quelling ethno-religious conflicts. In the North West is Operation Sara Daji and Operation Harbin Kunama. In the South-South, there is Operation Delta Safe formerly known as Operation Pulo Shield, this is complemented by

\footnotetext{
${ }^{16}$ Emma Powerful, "Port Harcourt Killings: We may resort to armed conflict - IPOB" in the Nigerian Pilot (Jan. 23, 2017). www.nigerianpilot.com/port-harcourt-killing. (Sourced on 8/3/17)

17 Emma Powerful, "Port Harcourt Killings: ..."

${ }^{18}$ Chiamaka Okoh, "There is No Middle Ground, It is Either Biafra or Death, IPOB" in Buzz Nigeria. ( buzznigeria.com/either-biafra-death-ipob. (sourced on 8/03/2017)
} 
Operation Crocodile Smile and Navy's Operation Tsera Teku. The militants in the Niger Delta mocked the military and established their own operation named Operation Crocodile Tears. In the South East we have Operation Iron Fence, as well as Operation Python Dance. In the South West, we have Operation Awase. ${ }^{19}$ What is very obvious from the above is that the military is over stretched and has almost more than it can chew at the moment. Anyone who reads the above reflectively will come to agree with me that regions in Nigeria have nothing against one another, but our rulers and the educated in authority have succeeded in creating hatred among various regions of Nigeria. For it is a fact that if it is any of the regions that is marginalizing others, then that region would be peaceful, far ahead of others in education, development and indeed in everything. But here we have agitation in all parts of the country. And every part claims marginalized by the Nigerian government. The question is, who is this Nigerian government? Everything boils down to the fact that what Nigeria is suffering from today is the problems created by the elites among themselves who make every region to believe what they believe today. Let us now look at Eph. 4:31-32 for solution.

\section{Exegesis of Eph. 4:31-32}

The Letter of St. Paul to the Ephesians along with Colossians, Philippians, and Philemon is a Captivity Letter. This is so because they were believed to have been written by Paul while in captivity. Ephesians has six chapters, our interest is on chapter four. This chapter has 32 verses. These verses can be divided into two major parts namely the Christian integrity (4:1-16) and Christian conduct (4:17-32), though the content of this second part stretched to chapter 5:20. Hence, Eph. 4:17-5:20 as a whole continues the emphasis on ethics begun at 4:1-16. 4:17-5:20 is united by two common purposes, firstly, the effort to distance the way of life of believers from that of nonbelievers, secondly, the determination to encourage unity among believers by means of adoption of ethical virtues and harmonious worship. ${ }^{20}$ 4: 17-32 can further be divided into the following subsections namely, old and new humanity (17-24); Rules for community (2532).Anyone who reads closely will easily discover that "Rules for Community" stretches from Eph. 4:25-5:5). The interest of this work is not really on the whole verses dealing with the rules of community life but on the centre of the information, which deals with the instructions on how peace could be brokered in a community (Eph. 4:31-32). The implication is that Eph. 4:31-32 is a unit within a unit. We shall look at it verse by verse since we have only two verses to deal with here.

Verse 31 is filled with moral exaltations or paraenesis which started from verse 29 down to verse 31 and end with verse 32. In verse 31, the author of Ephesians advised believers in a community and indeed everywhere to get rid of the following vices: "bitterness, anger, wrath, shouting, slander and all wickedness." These have their equivalents in Col 3:8 though not necessarily on the order it appears in Eph. 4:31 but basically they are the same though lesser in number. Col.3:8 lists the following as what a believer must get rid of for the sake of peaceful co-existence in a community, "anger, wrath, malice, slander, and filthy language." Both lists have four items in common. Similar listings can also be seen in 2Cor. 12:20 where Paul mentioned things he

\footnotetext{
${ }^{19}$ Senator Iroegbu, "With 10 Major Security Operations Across the Country, Military Stretched Too Thin" in This Day Newspaper (Sept. 11, 2016) https://www.thisdaylive.com/index. (Copied on 31/03/17).

${ }^{20}$ Margaret Y. MacDonald, Ephesians in The New Interpreter's Bible, One Volume Commentary (Nashville: Abingdon Press, 2010) 839
} 
would never like to meet in the Corinthian community anytime he visits and they are, "quarreling, jealousy, outbursts of anger, factions, slander, gossip, arrogance and disorder." Another list can also be seen in Gal. 5:19b-2121 where Paul lists the qualities of one who is living in the flesh and they include, "sexual immorality, impurity and debauchery, idolatry, and witchcraft, hatred, discord, jealousy, fits of rage, selfish ambition, factions, and envy, drunkenness, orgies and the like." Galatians is more comprehensive in presenting the fruit of the flesh, i.e. the qualities of one who lives according to the dictates of the flesh. Let us note that vice listing was a common literary form in the writings of ancient moralists; sometimes all the vices listed pertained to a particular topic, just we have 'anger' here as the central theme that encapsulates others. ${ }^{22}$

Let us now look at the above list of vices and study them one after the other. The first word on the list is 'bitterness' which comes from the Greek word pikria. According to Fritz, "it is a figurative term denoting that fretted and irritable state of mind that keeps man in perpetual animosity - that inclines him to harsh and uncharitable opinions of men and things - that makes him sour, crabby and repulsive in his general demeanor - that brings a scowl over his face and infuses venom into the words of his tongue". ${ }^{23}$ An embittered person is useless for peace making; for the moment he/she is engrossed in bitterness, reasoning is at a standstill. Such a person is capable of doing anything except doing anything that could lead to peaceful coexistence. The next word, the author of Ephesians urged all believers to abhor is 'anger' which comes from the Greek word phumos which expresses the temporary excitement or passion, a strong feeling of grievance and displeasure. What he really means here is the extreme form of anger which is rage. The next vice he abhors is 'wrath' which comes from the Greek word orgē which refers to the more subtle and a deep-flowing anger. This is a greater form of anger that most often goes with a desire for revenge. ${ }^{24}$ Bitterness, anger and wrath are almost one and the same thing. They tend towards the same direction. None of them has attribute of togetherness but divisiveness. Hence, they are "all fundamentally antisocial behaviours" 25 that must be avoided for the welfare of any society.

Similar to the above three is 'shouting' which comes from the Greek word kraugē which can mean the following, clamour, outcry, shouting, to demand noisily and desperately too, shout loudly. It is the cry of strife. From what we have said above it is only bitterness, anger and wrath that lead one into an outcry or shouting noisily for something. ${ }^{26}$ The next word that is not needed in a peaceful environment is 'slander' which comes from the Greek word, blasphēmia which can also mean, speaking evil of someone. It means also saying something false and damaging to somebody's reputation. ${ }^{27}$ It is from the Greek word blasphēmia that the English word blasphemy originates. Here it refers to the destruction of a neighbour's good name. It is a

\footnotetext{
${ }^{21}$ John Muddiman, Black's New Testament Commentaries: The Epistle to the Ephesians (New York: Continuum, 2001) 229.

${ }^{22}$ Craig S. Keeneer, "Ephesians" in The IVP Bible Background Commentary, New Testament (Illinois: Intervarsity Press, 1993) 549

${ }^{23}$ Fritz Rienecker, A Linguistic Key to the Greek New Testament (Michigan: Zondervan Publishing House, 1980) 534.

${ }^{24}$ Rienecker, 534-535

${ }^{25}$ Luke Timothy Johnson, The Writings of the New Testament, An Interpretation (Bangalore: Theological publications, 2009) 418.

${ }^{26}$ Rienecker, 535

${ }^{27}$ Rienecker, 535
} 
fact that it is a person of bitterness, anger and wrath as well as one with the tendency to descend into shouting that can slander somebody. The last and not the least is 'all wickedness,' or 'all evil' (pasēkakia). According to Fritz, kakia means "malice, badness. It is a generic term and seems to signify 'badhardiness,' the root of all those vices." 28 It is in the opinion of the author of Ephesians that all the above have to be removed (arthētō). The Greek word arthētō, 3rd person singular which isfirst aorist, passive imperative which comes from the verb airō means, "to pick up and carry away, to take away, to make a clean sweep." 29 The author of Ephesians advises that the above vices should be completely eradicated in the minds and hearts of believers for the good of the community in which they are. It is believed that if they have no existence in any persons mind or heart, it would not have any place in the community or society where the believer dwells. In short, it is like the Ephesians were urged to put off the old humanity (Col. 3:9-10) and embrace new humanity (Eph. 2:14-16; 4:32). All the vices listed here in v.31 are those that are disruptive of communal life. Hence, to avoid them is to be harmonious in the community. ${ }^{30}$

Verse 32 presents us with values with which the vices mentioned in verse 31 above could be replaced with. Verse 32 proves that nature abhors vacuum. If the contents of verse 31 are not good and eradicated, then there must be verse 32 to replace it. Verse 32 urges all, therefore, to be "kind to one another, tenderhearted, forgiving one another as God in Christ forgave you." The above three virtues counteract the vices of v.31. The author began his exaltation with the Greek word ginesthe which is 2nd person plural, present middle imperative from the word ginomai meaning 'to be.' Another word that attracts attention which the author used is the Greek word charizomenoi which is present middle, participle, nominative plural, masculine meaning, 'forgiving', it comes from the verb charizomai meaning 'to forgive'. The last virtue the author employed in this verse is echarisato which is 3rd person singular, first aorist, middle, indicative meaning "forgave". It implies that all should learn to forgive one another as God readily forgave us in Christ. This idea of forgiving one another as God forgave us in Christ reminds one of the Lord's prayer: "Forgive us our debts, as we also have forgiven our debtors" (Matt. 6:12). Though here "the imperative and the condition" are in reversed order. ${ }^{31}$ It is good to note here that, "Other moralists, including Greek and Roman non-Christians and Philo, appealed to the imitation of God for a standard of ethics. But non-Christian writers of Paul's day could not cite the example of a god who had lovingly sacrificed himself for his people." ${ }^{32} \mathrm{We}$ are urged in verse 32 to forgive one another as God readily forgave us in Christ. This can readily be seen also in Eph. 5:1-2. One can be forgiving as God forgave us in Christ if one is firstly, chrēstos which could mean the following, 'useful, worthy, good, kind, benevolent to one's neighbour; secondly, eusplagchnoi which literally means having 'healthy bowels', it properly defines one who is 'compassionate', and 'tender-hearted' towards one another. ${ }^{33}$ The meaning of this word is properly captured by this Igbo phrase, "afooma" (healthy bowels). It means the absence of wickedness and indwelling of goodness. The above three virtues are interconnected. Before one could avoid all the contents of verse 31, one must be kind, tenderhearted and one who readily

\footnotetext{
${ }^{28}$ Rienecker, 535

${ }^{29}$ Rienecker, 535

30 Paul J. Kobelski, The Letter to the Ephesians in The New Jerome Biblical Commentary ( Herndon: Geoffrey Chapman, 1997) 889

${ }^{31}$ Kobelski, 889

${ }^{32}$ Keeneer, 549

${ }^{33}$ Rienecker, 535
} 
forgives. Those are indispensable qualities of a good Christian which the author of Ephesians 4:31-32 advocates and urges all to imbibe if there must be peace in any community.

\section{Evaluation}

We have exposed above the sources through which human life as well as properties/infrastructure are being lost daily in Nigeria. The source of this loss of lives and properties is anchored on the assumption that the so called Nigerian government is not fair to all the sections of the country. The implication is that each section is nursing some anger against the Nigerian state and thus each section or rightly put, some warring factions from every part of the country carry arm to fight for the right of their so called section/region. What is very clear is that there has never been any section/region that gathers and establish one militant group or the other, instead the idea always start with an individual. It is the opinion of this paper that militant group used to emerge from few disgruntled elements and they sell their idea to their brothers and sisters who silently imbibe that; hence it becomes an alamode. Every militant group used to emerge like a continual drop of water that gradually culminates into an erosion or a wild fire that used to blossom from a little spark of fire. Every section of Nigeria seems to be fighting against the common interest of the nation. Simply put, every section of the country is fighting the centre without directly fighting against one another. Every section has their own militant group(s) peopled by youths who seem to be generally jobless and who feel that those in authorities are the source of their woes. The funny thing is that when these few are fighting and destroying federal government presence in their region, the ugly effects of their action affect all and sundry.

We listed many militant groups in different regions and noted that region the daily bread of these militant groups is bitterness, anger, wrath, shouting, slander and all wickedness. These are what the author of Ephesians names as the bane of any society and should be avoided by all means. If the above is their daily meals, they continually disobey another exaltation by the author of Ephesians when he says, "Do not let the sun go down while you are still angry, and do not give the devil a foothold" (Eph 4:26-27). The militants are those who have allowed several sunsets to set while they while they were still angry and thus they have embraced devil and all his directives. They nurse anger just as a hen sits on its eggs to nurse them for 21 days for them to hatch. The only difference between the hen and militants in their various act of nursing is that the hen nurses her eggs to bring new life into the world and militants nurse their own anger and bring death and destruction into the world. If "bitterness, anger, wrath, shouting, slander and all wickedness" of verse 31 is replaced with" kindness to one another, tenderheartedness, forgiving one another as God in Christ forgave you" then there will be proper healing, and reconciliation in Nigeria. The resultant effect of this will be development in all its ramifications which include human development and infrastructural development of the entire nation.

Recommendations: This work recommends that each section of the country should hold the political and traditional leaders from the section of their country accountable and by extension their religious leaders. This is because those who have been in political leadership especially are the ones who are always well to do and always far advanced than the majority of their community members. They used to deceive the members of their constituents with paltry gifts that blind them. To add to this paltry gift, is the blackmail with which they label leaders from other sections before their people as wicked and sectional. The sons and daughters of these 
political leaders, traditional leaders and religious leaders study in the best schools in the world and visits best hospitals when they are sick but ordinary Nigerians do not ask questions. During electioneering campaign, it is the ordinary Nigerians that they use to ascendthe throne on the promise to get our own national cake when in actual fact, they were really struggling for their welfare and that of their various families.

Secondly, true Federalism should be practiced in Nigeria where every section should be allowed to access the natural resources in their region and pay taxes to the Nigerian nation for international relations. The implication is that each section should be allowed to develop itself with all necessary amenities from the fruit of what is done in that region. This will enable everyone to hold their leaders in their regions accountable.

Conclusion: There is no alternative road to peace and stability if not for everyone to be kind to one another, tenderhearted towards one another, forgiving one another as God in Christ forgave us (v. 32). Pauline imperative is the solution. If Christian faith is enhanced and imbibed by all, through the general acceptance of the content of the Holy Bible as portrayed in Eph. 4:31-32, then national integration will be possible. 